\title{
Climate Consumption and Climate Pricing from 1940 to 1990
}

Michael I. Cragg, Columbia University Matthew E. Kahn, Columbia University

May 1997

Discussion Paper Series No. 9697-18

de $9697-2$

pages: 39 
Climate Consumption and Climate Pricing from 1940 to 1990

Michael I. Cragg and Matthew E. Kahn'

Columbia University

Department of Economics and SIPA

May 1997

\begin{abstract}
$\underline{\text { Abstract }}$
Compensating differentials studies have consistently found that temperate climate is capitalized into local wages and rents. This paper extends earlier single cross-section research by studying the evolution of climate expenditure over time by estimating the same climate compensating differentials model every decade from 1960 to 1990 . Over this time period, per capita expenditure on climate has increased (particularly for the elderly). This increase is explained by both a rise in consumption and also a dramatic shift in climate price capitalization. From 1960 to 1990 there has been a large two-and-a-third increase in climate prices capitalized into rents and a moderate 60 percent decline in climate prices capitalized into wages. Overall elderly households are paying much more for climate while the price paid by working households has roughly remained constant.
\end{abstract}

${ }^{1}$ Early versions of this paper were presented at the AEA Winter Meetings in New Orleans in 1997 and at the November 1996 Regional Science meetings in Washington D.C. This paper was written while Cragg was visiting RAND and Kahn was visiting Harvard. 


\section{Introduction}

Climate is the leading example of a spatially tied, exogenous, local public good. Compensating differential theory predicts that areas with more temperate climate should feature higher rents and lower wages (Roback (1982) and Rosen (1979)). Empirical studies have confirmed that climate is capitalized into the hedonic rental and wage gradient (Gyourko and Tracy (1989, 1991) and Blomquist, Berger, and Hoehn (1988)). ${ }^{1} \quad$ Such studies have focused on estimating a single set of hedonic prices at a point in time. We build on this approach by estimating climate prices in 1960,1970, 1980 and 1990. The estimated prices are used to construct climate price indices for working families and retired households.

Understanding the changes in the pricing and consumption patterns for climate is important for a variety of reasons. First, credible climate valuation estimates would inform policy makers on the benefits of mitigating Global Warming (Nordhaus (1996)). ${ }^{2}$ Second, it is important to quantify how the elderly's climate expenditure is growing over time since climate is an important health input. Our non-market public goods price index complements recent work on refining the market CPI index. Third, by estimating the same hedonic specification at four points in time, we contribute to the hedonic literature by studying the robustness and the plausibility of compensating differential estimates (Graves et. al. (1988)). Four sets of reduced form climate price estimates provides insights about the dynamics of climate demand. Since it is likely that climate demand has increased over time, it is interesting to study whether temporal trends in climate prices reflect this. Fourth, since the price of climate is determined by supply and demand in the regional housing and labor markets,

${ }^{1}$ Based on 1980 census data, Gyourko and Tracy (1991) report statistically insignificant impacts of precipitation, cooling degree days, humidity, sunshine and wind speed on labor market and housing market compensation. Heating degree days is statistically significant indicating that in colder climates families are compensating with a combination of lower housing prices and higher earnings. They estimate that the annualized full price (i.e. annual earnings net of annual housing price) of a one percent rise in heating degree days is $\$ 22.58$.

${ }^{2}$ Using county level data from the 1980 s, Nordhaus (1996) estimates wage regressions and concludes that plausible increases in carbon dioxide emissions could cause amenity losses of about 0.35 percent of aggregate U.S. wages which represents about 0.17 percent of U.S. GDP or $\$ 12$ billion dollars per year measured in 1995 prices and incomes. 
it is interesting to study how regional income convergence has affected estimated climate prices (Barro and Sala-i-Martin (1991, 1995), Oi (1997), Topel (1986)).

We find convincing evidence that climate is capitalized into earnings and rents in all four decades. The high degree of persistence in state average rents and earnings is suggestive that climate compensating differentials have not changed dramatically over time. ${ }^{3}$ We confirm this intuition using standard hedonic earnings and rental regressions. Although the pattern of hedonic pricing is consistent over time, the relative price of climate has changed over time for working and non-working families. Climate price increases are higher for the retired than for one worker or two worker families because there has been a large shift in climate capitalization from earnings to rents. ${ }^{4}$

While our climate price indexes demonstrate rising climate prices, we also document a large increase in the quantity of climate consumed. In combining our price estimates with quantity of climate consumed, we show that per capita climate expenditure has increased. However, we do not claim necessarily to have identified a shift in the structural "climate demand curve". Changes in reduced form climate prices and climate consumption can occur for reasons unrelated to the pursuit of increased climate consumption. For instance, if between 1960 and 1990 Minnesota families steadily increased their migration to Florida because of improved labor market opportunities then we could observe a rise in climate consumption (from the population shift), an increase in Florida's rents (due to the increased housing demand) and rising Florida wages (due to increased Southern labor demand). Such price dynamics would puzzle a compensating differential theorist who would expect to see earnings falling in areas experiencing employment and population growth. This example conveys how regional dynamics affect estimated climate price compensating differentials. ${ }^{5}$

\footnotetext{
${ }^{3}$ Between 1960 and 1990 , the correlation of average rents and earnings in a state is 0.61 and 0.70 respectively.

${ }^{4}$ This finding builds on work by Graves and Waldman (1991) that the elderly should be attracted to local amenities that are mainly capitalized into wages rather than rents. Since the elderly do not work, they are implicitly facing a lower price for such local public goods.

${ }^{5}$ This example illustrates the key identifying assumption in the hedonic literature that the spatial variation in earnings and rents is such that the population is indifferent across locations. In such a case, systematic net-migration flows from the Rust Belt to the Sun Belt cannot be explained. An alternative framework is that unanticipated demand and supply shifts affect
} 
Shocks to local labor and real estate markets that would affect the estimated compensating differential climate prices include: increased access to air conditioning, immigration, the decline in agriculture and increased southern road construction, the rising labor force participation rates of women, increased life expectancy and health and income of older citizens, declining Rust Belt Manufacturing, and OPEC oil shocks. ${ }^{6}$

While changes in these factors have undoubtedly affected the spatial equilibrium in wages and rents, a compelling case an be made that climate demand has increased over time. If climate is a normal good and if older people have a higher demand for climate, then as incomes rise and the population ages aggregate climate demand will have increased.

The paper proceeds by first measuring how aggregate climate consumption has changed over the last 50 years. We then measure whether the price of climate has increased through higher capitalization in rental prices and wages. Implicit prices are derived using standard hedonic techniques using data from 1960-1990. In the next section, we use our hedonic estimates to calculate climate price and expenditure indices. We then discuss the implications of our estimates and present additional evidence to study alternative non-climate demand theories that could rationalize our

spatial relative prices. This leads to migration opportunities but that the process of migration leads to spatial price adjustment such that prices rapidly converge to the compensating differentials. Topel's (1986) rational expectation model featured mobile agents responding to "new news" such that migrants did not respond to fixed levels of amenities but did migrate in response to new regional labor demand shocks leading to a new compensating differentials equilibrium. Rappaport (1997) provides a dynamic model that incorporates insights from growth theory with the standard static compensating differentials framework presented in Roback (1982) and Rosen (1979). Greenwood, Hunt, Rickman and Treyz (1991) present an interesting test of the equilibrium assumption by exploring what combination of rents and earnings would be required for net migration from state to state to equal zero. They conclude that: "Errors generated in the estimation of compensating differentials by erroneously assuming regional equilibrium therefore appear to be relatively minor, both quantitatively and qualitatively." (p. 1389).

${ }^{6} \mathrm{~A}$ variety of authors have examined the importance of factors which might affect regional labor demand and supply. For recent work which stresses the role of air conditioning see Oi (1997). For research on the trends in the spatial location of manufacturing see Crandall (1993). To examine the regional effects of shifts in defense spending, exchange rate shocks and oil price shocks see Davis et. al. (1996) and Topel (1986). Finally, for trends in leisure consumption see Costa (1997). 
findings. The final section concludes.

\section{Il. Increased Climate Consumption from 1940-1990}

We begin our analysis of changes in the valuation of climate by demonstrating how per capita climate consumption has changed over time. U.S. citizens are consuming more temperate climate over time. Due to population shifts, average per February temperature experienced by Americans has increased nearly 10 percent from 1960 to 1990 . Average February temperature has increased from 34.6 degrees in 1960 to 36.9 degrees in $1990 .^{7}$ It is well known that the greatest regional growth has occurred in the South and Western regions. In 1960,46\% of the population lived in the South or West regions while in 1990 this share had grown to 57\% (U.S. Statistical Abstract (1995) Table \#30). Interestingly, in both 1890 and also 1940, Darke County, Ohio was the median location in the nation such that half the population lived east of this county and half lived west of this county and half lived north of this county and half lived south of it. Between 1940 and 1990, the median location shifted to Monroe, Indiana while lies approximately 110 miles west and 75 miles south of Darke, Ohio (U.S Statistical Abstract 1995).

To further explore changes in climate consumption, we have constructed the cumulative distribution function for February temperature for the non-elderly and elderly in 1940 and $1990 .^{8}$ In figures 1 and 2 the horizontal axis measures temperature while the vertical axis measures the fraction of people who are consuming at most the corresponding average temperature. As the cumulative distribution function shifts right, people are experiencing warmer climates. Furthermore, as the cumulative distribution function becomes more bowed, the consumption of temperature becomes more equal. Figure 1 shows that in 1940, half of the population experienced average

${ }^{7}$ We calculate the national weighted average using state average temperature weighted by the state's percentage of the national population.

${ }^{8}$ Using Public Use Micro Census data discussed in the data appendix we identified each person's state of residence and merged on average February temperature for that state. Sorting the data by February temperature yields the cumulative distribution function which is plotted in Figures 1 and 2 . 
February temperatures less than 30 degrees. By 1990, fewer than 40 percent of people experienced average February temperatures below freezing. Figure 1 shows that as a whole the nation is consuming more climate per capita. Furthermore, Figure 1 also demonstrates that the consumption of climate is becoming less equal. There has been no change in temperature consumption in the bottom fifth of the population while the top 80 percent are consuming much more climate. Figure 2 shows that the shifts in temperature consumption for the elderly are much more pronounced. This reflects the large elderly migration to the South and Southwest from cooler regions (Biggar (1984), Rogers (1992), Muth (1991)).

To document that the population has shifted to warmer areas, we examine migration patterns. As discussed in the data appendix, the Census identifies both a household's current state of residence and also their state of residence five years earlier. Rather than present a 48 by 48 state transition matrix, we assign states to one of four groups based on February temperature and present a four by four transition matrix which links climate rankings of one's origin and destination state. ${ }^{9}$ Table 1 shows that in 1940, 39 percent of movers younger than age 65 and 47 percent of movers older than age 65 increased their consumption of February temperature. By 1990, movers are much more likely to increase their climate consumption. Almost 60 percent of the elderly movers and almost 50 percent of working age movers increased their consumption of February temperature while only a quarter of the movers relocated in a colder location. Another indicator that migrants are pursuing better climate is a correlation of -0.57 between February temperature and the fraction of a state's population that was born in that state (calculated using the 1990 Census). This indicates that people born in cold states tend to move away from their birth state.

Thus far, the results in this section have only focused on February temperature. To study additional climate proxies, we present net migration equations for 1940,1980 and $1990 .^{10}$ The

${ }^{9}$ Each of the 48 states are assigned to one February temperature category. The states with mean temperature below 23.8 are assigned to the first quartile. States with February temperature between 23.8 and 33.1 are assigned to the second quartile and states with temperature between 33.1 and 39.6 are assigned to the third quartile. States with temperature above 39.6 are assigned to the fourth quartile. This partition is such that each of the groups includes twelve states.

${ }^{10}$ Only the 1940,1980 and 1990 Censuses include the question of which state people lived in 5 years earlier. 
regressions examine the rate at which the net population of each state changed as a function of four climate variables: February temperature, July temperature, the level of humidity and the degree of sunshine. ${ }^{11}$ In Table 2, we see that net migration of the elderly is most sensitive to February temperature and that its effect has grown over time. For the rest of the population, July and February temperatures are the climate variables most important in location choice. While February temperature has consistently been important, the negative effect of July temperature has declined over time, perhaps as a result of the wide-spread availability of air conditioners (Oi 1997).

While the evidence in this section demonstrates that per capita consumption of climate has increased, it is impossible to say whether the demand for climate has changed without information on the evolution of hedonic prices. Increased consumption could simply reflect a decline in the price of warm climate so that what we observe is movement along a stable demand curve. If climate prices increased, then rising consumption is consistent with the hypothesis that climate demand has increased over time.

\section{Measuring the Change in Climate Prices}

\section{III.A Empirical Approach}

In this section, we use the compensating differentials framework (Roback (1982), Rosen (1979), Gyourko and Tracy (1992), Blomquist, Berger and Hoehm (1988), Gabriel, Mattey and Wascher (1996)) to estimate how climate prices have evolved from 1960 to 1990. The starting point of all hedonic studies is an assumption that the economy is in equilibrium so that spatial variation wages, rents, and amenities are such that the marginal person and firm are indifferent across locations. Assuming that migration costs are low, spatial variation in observed prices represents an equilibrium compensating differential for non-market spatially tied goods such as climate. As factors

${ }^{11}$ We experimented with breaking net migration flows into their inflow and outflow components and found that only inflows are sensitive to climate differences. People are far less sensitive to climate in the decision of whether to move. However, conditional on moving, migrants are sensitive to location attributes in their choice of destination. 
affecting the supply and demand for labor or housing change over time, then we would expect to see a shift in hedonic prices for climate. ${ }^{12}$ We test four hypotheses of interest:

Hypothesis One - The demand for climate has been in a steady state so that climate compensating differentials have not changed over time.

Hypothesis Two - The demand for climate has steadily increased so that rental prices have risen and earnings have fallen in temperate places.

Hypothesis Three - The effect of July temperature and humidity have fallen over time as cheaper air conditioning mitigates their impact on wages and rents. ${ }^{13}$

Hypothesis Four - Increased numbers of senior citizens and increased women's labor force participation over time have contributed to a shift of climate capitalization from earnings to rentals such that families now pay for climate through rental capitalization.

We quantify how hedonic climate prices have evolved by estimating climate compensating differentials at four points in time. We estimate reduced form cross-sectional earnings and home price regressions as in equations $(1$ and 2$) .^{14}$

${ }^{12}$ We recognize that if the supply of labor and the supply of housing were perfectly elastic then quantities and not prices would clear regional markets. Regions with positive demand shifts would experience an influx of migrants and increased housing construction. However, migration costs, transaction costs and issues of irreversible investment make such extreme assumptions unlikely.

${ }^{13}$ This hypothesis recognizes that people demand comfort which is an increasing function of February temperature but a decreasing function of July temperature. Only states such as California offer the bundle of warm February but moderate July. Southern states are a bundle of hot February and hot July. Air conditioning allows one to unbundle the effective consumption of warm February and avoid the warm July by spending more time inside. Thus the growth in an explicit market for climate allows a reduction in capitalization in the implicit market.

${ }^{14}$ Previous hedonic studies have estimated hedonic wage rather than earnings regressions. Wages are constructed by dividing earnings by hours worked. Thus, the typical hedonic study's dependent variable is constructed as the difference in log of earnings and log of hours. Wage estimates will be biased towards zero if climate and leisure are complements eg. if base salaries are constant across space, but salaried workers reduce their labor supply in nice places, then hourly wages will be higher in nice areas. By using earnings rather than wages as our dependent variable, our method calculates the total private consumption sacrificed in consuming a 


$$
\begin{gathered}
\log \left(\text { earnings } s_{i j t}\right)=B_{t} * X_{i t}+\gamma_{t} * Z_{j}+\epsilon_{i j t} \\
\log \left(\text { rent }_{i j t}\right)=\phi_{t} * V_{i t}+\psi_{t} * Z_{j}+U_{i j t}
\end{gathered}
$$

where $i$ is a person, $j$ indicates a state and $t$ is time and $X$ and $V$ are respectively characteristics of the worker and the housing unit and $Z$ are characteristics of the geographical location that the worker or home are tied to. In this paper, we represent climate along four dimensions that include a state's historical average February temperature, July temperature, percentage days of sunshine and humidity (see the Data Appendix). Estimates of $\gamma$ and $\psi$ are used to generate non-market price indices based on implicit capitalization into wages and rents.

Several issues arise in estimating equations (1) and (2). First, to be able to go back in time as far back as 1960 we had to use the state rather than the city (smsa) as the geographical unit of analysis. Climate is an attractive amenity to quantify since its cross-state variation is larger than its within state variation. Cross-state hedonic estimates of crime's capitalization or school quality would be much more suspect. By focusing only on climate, we implicitly assume that variables in the error term such as local crime levels are uncorrelated with climate. A second problem with our estimation strategy is that, except implicitly for housing, we do not correct for regional cost of living differences since adequate regional price deflators do not exist. A third problem is that heteroskedasticity in the error term arises across states due to omitted factors and differences in the size of states. We follow the recommendations of Moulton (1986) and Gyourko and Tracy (1988) by computing Huber-White corrected standard errors where grouping is done by state. A final issue with the specification in equations (1) and (2) is that it assumes there is a national market in housing and labor. Note that the price per unit of human capital varies over time but not across regions. ${ }^{15}$

location's climate. In figures presented later in the paper, we present some evidence on slightly higher average annual hours worked in colder climates.

${ }^{15}$ The hedonic literature has focused on assuming that all spatial variation in earnings and rents is generated by differences in quantities of amenities $(Z s)$ not differences in prices $\left(B_{t}\right)$ across space (see Gyourko and Tracy $(1989,1991)$ and Blomquist, Berger and Hoehm (1988)). Heckman and Scheinkman (1987) present a skill bundling model that generates differences in regional factor prices because a person cannot sell her labor to two labor markets at the same 


\section{III-C - Estimated Price Changes}

Table 3 presents two sets of hedonic earnings regressions (see equation 1). Each set of regressions estimates the same specification in 1960-1990 thereby demonstrating how climate prices capitalized into earnings have evolved over time. We include a dummy for California in the earnings regressions since our experimentation found that our climate price estimates are very sensitive to not dummying out California. ${ }^{16}$ The units are 1990 dollars.

For the non-climate variables, we find the typical time trends that are well documented in the labor literature (see Juhn, Murphy, Pierce (1993)). The coefficients we report can be regarded as percentage returns because we estimate log earnings regressions. The returns to an extra year of education fell from 0.068 in 1960 to 0.052 in 1970 and then steadily rose to 0.061 in 1990 . In addition, the nonlinear effect of having a college degree has risen from 0.049 to 0.078 . As expected, the premium for being white declines over time from 0.29 to 0.14 and the returns to being in a professional occupation was constant from 1960 to 1970 and then doubled between 1970 and 1990 . Finally, married men consistently earn roughly 10 percent more than non-married men.

A compensating differential model would predict that higher February temperatures and more sunshine should lower earnings while higher July temperatures and higher humidity should raise them. Except for the coefficients on humidity, we find support for this basic hypothesis. An extra 10 degrees of February temperature (a standard deviation) lowers earnings by approximately 5 percent in 1960, 3 percent in 1970 and 1980 and by 1 percent in 1990. These estimates are statistically significant at the 1 percent level in all years except for 1990. For increases in July

time.

${ }^{16}$ California is a high earnings, high climate state which experienced differential trends to the rest of the country. Its biggest difference from the rest of the country is its experience with immigrants. From 1960 to 1990 , the percentage of the male workforce who were immigrants in California rose from 10.3 to 26.9 percent while for the rest of the country the trend was from 5.9 to 9.9 percent. Californian immigrants are also different to the rest of the country. In 1970 the Californian immigrants earned 16 percent less than native Californians while in 1990 they earned 28 percent less. Natives in the rest of the country earned 1 percent less than natives in 1970 and 11 percent less in 1990 (Schoeni, McCarthy and Vernez (1996)). 
temperature, we find that an extra 10 degrees ( 2 standard deviations) raises earnings by 16 percent in 1960. Similar to the price pattern for February temperature, capitalization falls steadily across decades such that by 1980 an extra 10 degrees raises earnings by 10 percent and by 1990 by a statistically insignificant 4 percent. Thus, our first finding is that capitalization for extreme climate is falling over time. Areas such as Florida with relatively warm February temperature and warm July temperature have offsetting effects while areas such as Oregon with warm February temperature and cool July wages are rising. Similar to February temperature, sunshine's capitalization is generally falling over time. By 1990, a 10 percentage point rise in possible sunshine lowers earnings by 7 percent in contrast to 13 percent in 1960.

The rental regressions measuring the degree of climate capitalization into housing rental prices are presented in Table 4. The regressions include controls for the number of rooms and age of the housing. For the sake of brevity, we omit the age coefficients and note the rooms coefficient indicates that the price of an extra room has increased over time. The capitalization pattern of climate into rentals contrasts with the capitalization into earnings. From 1960 to 1990, rental capitalization grew dramatically. While a 10 degree increase in February temperature decreased rents by 7 percent in 1960, by 1990, such an increase increased annual rents by 9 percent. This estimate is statistically significant at the 5 percent level. In contrast, higher July temperatures lower rents by a statistically significant amount in all 4 decades and its coefficient's magnitude grows monotonically over time. This compensating differential almost doubles from 2.5 percent per degree in 1960 to 4.8 percent in 1990. The increased capitalization of February and July temperature in rentals contrasts with their reduced capitalization into earnings. Finally, humidity had an insignificant effect on rentals in all four regressions and sunshine capitalization is constant from 1960 to 1980 after which it doubles.

The hedonic earnings and rental estimates of climate clearly reject our first hypothesis by showing that the hedonic pricing equilibrium has shifted over time. We also reject the second hypothesis that the steady state has shifted steadily such that capitalization into wages and rents have both increased. Surprisingly, we find little support for our third hypothesis that the importance of July temperature and humidity should be reduced due to the widespread availability of air 
conditioning. ${ }^{17}$

We do report evidence supporting our fourth hypothesis that capitalization has shifted from earnings to rentals. Two explanations for this shift are the rise in women's labor force participation from 1960 to 1990 and the increasing share of the elderly in the population. The former implies that without a shift in capitalization, families with two earners pay considerably more than single earner households to live in nicer areas. Over time the elderly are becoming "less infra-marginal" and "more marginal" because the absolute number of elderly are growing over time and less of them are living with their children. As growing numbers of retired workers have moved to temperate climates rents would be bid up relative to wages.

\section{III.D Climate Price and Expenditure Indices}

Analogous to the CPI index, our climate prices estimates can be used to construct a nonmarket local public goods price index. Our climate estimates provide a valuable tool for summarizing how total climate expenditure and the overall price of climate have evolved. They are also valuable for assessing the incidence of changing climate prices. As climate price and consumption patterns have changed over time do the elderly or working families bear most of the costs? It is possible that the rising rental capitalization overwhelms the falling earnings capitalization so that both elderly and working families are paying more for the climate they consume.

To answer these questions, we calculate price indexes for earnings and rents separately and then combine them together. We also calculate expenditure indexes across different family types and investigate whether changes in prices or changes in quantities are responsible for large shifts in total climate expenditure across the major demographic groups.

Conceptually, the earnings expenditure on climate in each state is the sum across all workers of the price capitalized in wages for each type of amenity multiplied by the quantity of the amenity

${ }^{17}$ Since July temperature is highly correlated with February temperature it may be difficult to isolate the individual climate prices for the two amenities separately. California, Washington and Oregon are the only states that have relative warm February temperature and low July temperature which break the southern strong correlation between temperature proxies. 
in the state. National expenditure is simply the sum across the 48 states. The hedonic index number method uses this intuition by calculating the change in climate expenditure as

$$
\text { expenditure change }=\frac{\sum_{j=1}^{48} s_{1, p} p_{1 j}^{\prime} x_{1 j}-\sum_{j=1}^{48} s_{0 j} p_{0 j}^{\prime} x_{0 j}}{\sum_{j=1}^{48} s_{0 j} p_{0, j}^{\prime} x_{0 j}}
$$

Total climate expenditure $p_{j l}{ }^{\prime} x_{j l}$ in each state $j$ is calculated by using the hedonic price estimates $p_{j l}$, which are simple transformations of the hedonic coefficients from our log-linear hedonic regressions. The total national climate expenditure in year 1 is the weighted sum across all states using as weights $s_{j l}$, the populations living in each state. Growth in total expenditure is simply the percentage change in total annual climate expenditure.

We calculate the price index through a simple transformation of our expenditure index. Because expenditures rise through either increases in prices or quantities consumed, we hold quantities constant at their 1960 levels. Equation (4) shows how the price index is calculated by holding the quantities $x_{j l}$ and populations $s_{j l}$ at their period 0 values

$$
\text { price change }=\frac{\sum_{j=1}^{48} s_{0 j} p_{1 j}^{\prime} x_{0 j}-\sum_{j=1}^{48} s_{0 j} p_{0 j}^{\prime} x_{0 j}}{\sum_{j=1}^{48} s_{0 j} p_{0, j}^{\prime} x_{0 j}}
$$

Operationally, we calculate the price index using the 1960 population locations. Analogous to the price index, we can also create a quantity index by holding prices constant at their period 0 values and allow quantities to change.

Table 5 summarizes our three basic findings on decomposing climate expenditure into price and quantity changes. First, total consumption has risen over time. From 1960 to 1970 rental expenditure fell slightly while earnings expenditure rose 32 percent. From 1970 to 1990, rental expenditure rose rapidly with almost a nine fold increase from 1980 to 1990. From 1980 to 1990, earnings expenditure fell moderately. For a working family, the decline in earnings expenditure was not large enough to offset the rising rental expenditure so that from 1960 to 1990, total expenditure 
increased 60 percent. For retired households, rising hedonic rental price and the migration of the elderly to nicer areas has led to a four-fold increase in climate expenditure.

Second, holding prices constant, only a small fraction of the rapid rise in climate expenditure is explained by the rise in the total quantity of climate consumed. From 1960 to 1990 , the total quantity of climate consumed by working families doubled while the elderly have witnessed a much larger increase of 240 percent. These shifts in consumption are large on an absolute level but small relative to the dramatic rise in climate expenditure.

Finally, we see very different trends in climate capitalization into rentals and earnings. From 1960 to 1970 , both earnings and rental prices change little. However, from 1970 to 1980 the price of climate capitalized in rents more than doubled while the price capitalized in earnings fell 20 percent. From 1980 to 1990 this pattern is even more dramatic as climate prices in the housing market increased by a factor of 6 while those in the labor market fell 40 percent.

For working households the decline in earnings capitalization is large enough to offset the rise in housing capitalization so that overall, the price of climate for working households has fallen 20 percent from 1960 to 1990 . Thus, the rise in working family climate expenditure is explained by the population shifting to nicer areas.

For the elderly, climate has become much more expensive: in 1990 climate was more than twice as expensive as in 1960 because they only pay for climate through the housing market. Thus, most of the rise in the elderly's expenditure on climate is the result of the shift in hedonic pricing away from earnings towards rentals.

The repeated hedonic regressions we have estimated reveal three important facts about how climate pricing and consumption have changed over the last thirty years. First, the population has shifted so that the consumption of climate has risen for both working families and more dramatically for the elderly. Second, there has been a striking rise in rental capitalization. Third, earnings capitalization has declined so that the relative price of climate has increased for the elderly and fallen for working families.

The estimated price increases are not inconsequential. In 1990, the average working single earner household paid a total of $\$ 3,418$ for climate capitalized into rentals (\$938) and earnings 
$(\$ 2,480)$. The average elderly household in 1990 paid $\$ 1,271 .^{18}$ Thus, the CPI is likely to be missing a large component by ignoring non-market goods. This omission is likely to affect the elderly more due to offsetting changes in rental and earnings capitalization.

\section{Does the Climate Price Index Reflect Changes in Climate Demand?}

Our findings that the quantity of climate consumed increased (for both elderly and working households) and that the price of climate has increased (for the elderly) or stayed constant (for working households) are suggestive that climate demand has increased. However, a rise in climate demand can neither explain declining wage capitalization nor can it explain why rentals and earnings are growing in southern areas (Topel 1986). For firms to remain indifferent about staying in the South as rents rise, wage rates would have to fall to offset rising rental rates. Alternatively, in the face of rising rents, Southern firms would only be willing to stay if Southern labor productivity increased. Without introducing local labor demand shifts, it is difficult to explain the fact that earnings are rising in warmer states (Oi 1997).

We posit two explanations for the simultaneous rising price and consumption of climate by the elderly together with rising climate consumption but falling climate prices for working families. First, we believe that the aging of the population together with a shift in elderly preferences such that the elderly are more concentrated in temperate climates have increased rental capitalization. Second, rising Southern labor demand driven by increased labor productivity have raised earnings in temperate climates.

A number of authors have documented rising earnings and employment in the South. Mallick (1993) showed that in 1951, such Southern states as Mississippi and Arkansas had the lowest percapita income in nation but between 1951 and 1989, they ranked amongst the highest in growth. Nonetheless, in 1989 their level of per capita income is still amongst the lowest in the country. Oi (1997) presents additional evidence: from 1950 to 1990, the ratio of Southern per-capita income

\footnotetext{
${ }^{18}$ The numeraire in these calculations is the climate of Minnesota. i.e. we normalize expenditures such that Minnesota residents pay nothing.
} 
relative to the national mean grew from 0.76 to 0.90 . At the same time, there have been dramatic changes in employment and productivity. Between 1954 and 1987, the South's share of manufacturing employment grew from 20.3 percent to 31.6 percent and value added per worker rose from $\$ 88.9$ to $\$ 96.3 .^{19}$ Oi's thesis is that the adoption of the air conditioner has allowed increased worker productivity in the south. Oi points out that from 1970 to 1990, air conditioning rates in the South rose from 58 to 91 percent while at the national level they only rose from 44 to 70 percent. His discussion suggests that lower Southern wages and increasing productivity drove Southern economic development. Thus, Southern economic development and not just rising climate demand is partially responsible for rising rents and earnings.

It is possible that our estimated climate price trends represent temporal shifts to regional labor demands rather than underlying shifts to climate demand..$^{20}$ One simple test of the hypothesis that climate price shifts are proxying for labor demand shifts is to study labor supply in warm and cold places over time. As discussed in Blanchard and Katz (1992), women's labor force participation is one margin that can help the local labor market clear. A relatively higher rise in women's labor force participation and annual hours worked in warmer February climate areas could be interpreted as evidence that labor demand is increasing sharply in these areas. To study this hypothesis, we study the relationship between climate and work by categorizing propensities to work and annual hours worked (for all people between ages 18 and 65) according to the climate in their state of residence. As in Table 1, we place all states into to four mutually exclusive and exhaustive February temperature categories. Figures 3-6 present our findings. We replicate the well known fact of a huge increase in women's labor force participation and that average hours worked have increased for

${ }^{19}$ Additional research on regional convergence is presented in Amos (1991), Carlino and Mills (1996a,1996b), Barro and Sala-I-Martin (1991, 1995), Sahling and Smith (1983), Treyz (1991), Mieszkowski (1979), Terkla, and Doeringer (1991).

${ }^{20}$ Increased business activity and increased climate demand are not mutually exclusive hypotheses. It is possible that labor demand is growing in the south partially because climate demand has been expected to continue to grow. Following Krugman (1991), if manufacturing firms attempt to minimize transport costs and land costs while exploiting economies of scale, they would want to locate where the consumer base is growing. In this case, consumer climate pursuit could represent a commitment device such that firms view southern areas as increasingly profitable. 
women from 1970 to 1990 but we find no evidence of a "warm February effect". We find no evidence that women's or men's labor force activity has increased differentially in the warmest climates. The figures suggest no evidence that warmer labor markets are "tightening" over time. This is consistent with Blanchard and Katz's (1992) and Bartik's (1991) claim that migrants clear the local labor market.

Examining the tradeoff between consumption and amenities implicit in the location choice of migrants provides information on how the demand for climate may have changed over time. ${ }^{21} \mathrm{We}$ turn to findings from our earlier research on migration and climate pursuit (Cragg and Kahn 1997). ${ }^{22}$ In that paper, we employed a conditional logit framework to study how migrants tradeoff climate and consumption when choosing where to live. ${ }^{23}$ McFadden (1981) and Small and Rosen (1981) have shown that the results from such a regression yield legitimate willingness to pay measures. In our nonlinear specifications, we find that climate is a normal good. We also find that the elderly's willingness to pay for climate is several times larger than younger cohorts. This evidence suggests that the rising post-war income has shifted out the demand for climate. This evidence validates our intuition that the demand shift is particularly pronounced for elderly since their share of the population has been growing as has their post-retirement income due to post-war booms in the value

${ }^{21}$ There is a large literature exploring whether hedonic techniques can be used to infer structural demand parameters (Rosen (1974), Bartik (1987), Epple (1987) and Palmquist (1991). Our hedonic estimates from 1960 to 1990 yield 4 price estimates and 4 quantity estimates. If supply side shocks to the housing market and labor demand shifts could be viewed as exogenous to climate demand then such shocks would provide information on how sensitive is climate consumption to changes in its price. Unfortunately, our four data points are clearly not enough information to estimate demand parameters using the hedonic "two step" approach.

${ }^{22}$ Several authors have explored the dynamics of the relationship between migration, climate and proxies for economic opportunity. Mueser and Graves (1995) present county level evidence based on data from 1950-1990 and find that controlling for county per-capita income there is a positive correlation of net migration and February temperature but they find that this correlation is growing smaller over time. Barro and Sali-I-Martin (1995) show that decade changes in net population growth are positively related to initial state income level and to climate. They find that net migration rates are highly correlated over time.

${ }^{23}$ One interesting paper that combines migration data with hedonic quality of life hedonic data is Berger and Blomquist (1991). They study whether migrants are overcoming migration costs to move to the counties that their quality of life metric ranked as high. 
of real-estate and assets.

\section{Conclusion}

This paper applied standard hedonic quality of life techniques to generate a time series on trends in climate prices from 1960 to 1990 . Since climate is an important non-market good, it is important to quantify how its price has changed over time. We find that climate is capitalized into earnings and rents in all four specifications but that the pattern of capitalization has changed. From 1960 to 1990, rental capitalization has dramatically risen while earnings capitalization has fallen. This shift in climate prices has meant that climate has become $21 / 3$ times more expensive for the elderly but moderately less expensive for families still working. The price and population changes suggest that the elderly are bearing much of the cost of shifting hedonic prices. We know of no hedonic studies that have explored the robustness and plausibility of hedonic prices over the interval we have explored. We find that hedonic climate price estimates are not stable over time and that a simple increased climate demand model cannot rationalize the pricing patterns and the increased consumption patterns.

Even though climate prices have risen for the elderly and remained close to constant for the rest of the population, the quantity of climate consumed has risen substantially as the population of both elderly and non-elderly has shifted towards high climate areas. While there appears to be a shift in the demand for climate due to higher post-war incomes or a rise in leisure (a complement with climate), this can not explain the simultaneous rise in Southern earnings and rents. A rise in Southern labor productivity together with increased demand for climate can explain the simultaneous rise in Southern wages, rents and net migration.

For users of hedonic models, these findings have both negative and positive implications. We are able to rationalize the patterns of changing capitalization and consumption by appealing to intuitively plausible shifts in both preferences and also spatial shifts in productivity. The importance of our appeal to a shift in productivity to explain our findings demonstrates that the hedonic researcher cannot simply interpret changes in climate pricing as a reflection of changes in the climate demand. Thus hedonic researchers must take care in recognizing that local public goods (even if not 
publicly provided like climate) are tied to a region's economy which means that observed compensating differentials will be affected by shifts in local labor and housing demand and local labor supply shifts (immigration).

Building on this paper's findings, future work might explore the regional implications for the upcoming Baby Boomer retirement. A macro literature has explored how this large cohort affects national savings, the stock market, and aggregate real estate prices. We know of no work projecting how regional real estate prices will be affected by the large number of seniors pursuing climate. It is reasonable to predict that there will be increased capitalization of climate into rents and away from earnings (Welch (1979), Berger (1986), Mankiw and Weil (1989)). 
References

Amos, O. "Divergence of Per-Capita Real Gross State Product by Sector 1963-1986. " The Review of Regional Studies. 21, 221-234; 1991.

Barro, R.and X. Sala-I-Martin. "Convergence Across States and Regions". Brookings Papers on Economic Activity, 1, 107-158; 1991.

Barro, R. and X. Sala-i-Martin. Economic Growth. McGraw Hill 1995.

Bartik, Timothy J. (1991). Who Benefits from State and Local Economic Development Policies? Kalamazoo, Mich: W.E. Upjohn Institute for Employment Research.

Berger, M. "The Effect of Cohort Size on Earnings Growth an Reexamination of the Evidence". Journal of Political Economy. June 1985 93(3) p561-575.

Berger, $\mathrm{M}$ and G. Blomquist. Mobility and Destination in Migration Decisions,. Journal of Housing Economics, 2, 37-59, (1992).

Biggar, J.C The Graying of the Sunbelt A Look at the Impact of the US Elderly Migration.. 1984

Blanchard, Olivier Jean and Lawrence F. Katz (1992). "Regional Evolutions," Brookings Papers on Economic Activity, pp. 1-75.

Blomquist, G. M. Berger and J.Hoehn. New Estimates of Quality of Life in Urban Areas, American Economic Review, 78, 89-107. (1988).

Carlino, Gerald and Leonard Mills. "Testing Neoclassical Convergence in Regional Incomes and Earnings." Regional Science and Urban Economics . 26 (1996) 565-590.

Carlino, Gerald and Leonard Mills. "Convergence and the U.S. States: A Time-Series Analysis". Journal of Regional Science. Vol. 36. No. 4, 1996; 597-616.

Costa, Dora. Less of a Luxury: The Rise of Recreation Since 1888. MIT Working Paper 1997.

Cragg, M and M. Kahn, New Estimates on Climate Demand: Evidence from Location Choice, forthcoming Journal of Urban Economics.

Crandall,-Robert-W. Manufacturing on the Move. Washington, D.C.: Brookings Institution, 1993.

Davis, S. and P. Loungani and R. Mahidhara. "Regional Unemployment Cycles" 1995 mimeo. 
Gabriel, Stuart and J. Mattey and W. Wascher. "Compensating Differentials and Evolution of Quality of Life among U.S. States" Federal Reserve Bank of San Francisco, 96-07, June 1996.

Graves, Philip E., and Donald M. Waldman. "Multimarket Amenity Compensation and the Behavior of the Elderly." American Economic Review 81 (December 1991): 1374-1381.

Graves, Philip, James Murdoch, Mark Thayer, and Don Waldman. "The Robustness of Hedonic Price Estimation: Urban Air Quality." Land Economics 64 (August 1988): 220-242.

Graves, P. A Life-Cycle Empirical Analysis of Migration and Climate, by Race," Journal of Urban Economics, 6, 135-147. (1979).

Graves, P. Migration and Climate, Journal of Regional Science, 20, 227-237. (1980).

Greenwood, M. and G.L. Hunt "Migration and Interregional Employment Redistribution in the United States". American Economic Review. 74, no. 5 pp. 957-969.

Greenwood, M. Gary L. Hunt, Dan S. Rickman, and George I. Treyz. "Migration, Regional Equilibrium, and the Estimation of Compensating Differentials." American Economic Review 81 (December 1991): 1382-1390.

Gyourko, Joseph, and Joseph Tracy. "The Structure of Local Public Finance and the Quality of Life." Journal of Political Economy 99 (August 1991): 774-806.

Heckman, James and J. Scheinkman (1987). "The Importance of Bundling in a Gorman-Lancaster Model of Earnings," Review of Economics Studies, 54, pp. 243-255.

Juhn, Chinhui, Kevin M. Murphy, and Brooks Pierce. "Wage inequality and the rise in returns to skill," Journal of Political Economy. v 101 n3. Jun 1993. p. 410 - 442.

Krugman, Paul. Geography and Trade. MIT Press 1991.

Longino, Charles. "The Forest and the Trees: Micro-level considerations in the study of geographic mobility in old age" Elderly Migration and Population Redistribution. Edited by Andrei Rogers; 1992 Wiley Press.

Mallick, Rajiv. "Convergence of State Per Capita Incomes: An Examination of its Sources," Growth and Change 24, 321-3401993.

Mankiw, G. and D. Weil. "The Baby Boom, Baby Bust and the Housing Market". Regional Science and Urban Economics. (May 1989) V. 19. p. 235-258.

McFadden, D. "Econometric Models of Probabilistic Choice," in Structural Analysis of Discrete 
Data with Economic Applications, (C. Manski and D. McFadden, eds.) MIT Press: cambridge.

Mieszkowski, Peter. "Recent Trends in Urban and Regional Development." in P. Mieszkowski and M. Straszheim (eds). Current Issues in Urban Economics. Johns Hopkins University Press 1979.

Moulton, Brent R. "Random Group Effects and the Precision of Regression Estimates." Journal of Econometrics 32 (1986): 385-397.

Mueser, P and P. Graves. Examing the Role of Economic Opportunity and Amenities in Explaining Population Redistribution." Journal of Urban Economics; 37; 176-200 (1995)

Muth, R. "Supply Side Regional Economics". Journal of Urban Economics; 29; 1991 63-69.

Nordhaus, W. Climate Amenities and Global Warming. mimeo (1996).

Oi, Walter. "Welfare Implications of Invention". Edited by Tim Bresnahan and Robert Gordon. The Economics of New Goods. NBER 1997.

Palmquist, R. "Hedonic Methods." In Measuring the Demand for Environmental Quality. Contributions to Economic Analysis, no. 198, edited by John B Braden and Charles D. Kolstad. New York, Elsevier Science, 1991.

Rappaport, J. “Local Growth”. Harvard University mimeo 1997.

Roback, J. Wages, Rents and the Quality of Life," Journal of Political Economy, 90. 1257-1278. (1982).

Rogers, Andrei. "Elderly Migration and Population Redistribution in the U.S" Elderly Migration and Population Redistribution. Edited by Andrei Rogers; 1992 Wiley Press.

Rosen, Sherwin. "Hedonic Prices and Implicit Markets: Product Differentiation in Pure Competition." Journal of Political Economy 82 (January/February 1974): 34-55.

Rosen, Sherwin. "Wage-based Indexes of Urban Quality of Life." In Current Issues in Urban Economics, edited by Peter Mieszkowski and Mahlon Straszheim. Baltimore, Johns Hopkins University Press, 1979.

Sahling, L. And S. Smith. "Regional Wage Differentials, Has the South Risen Again?" Review of Economics and Statistics. 65; 131-135; 1983.

Schoeni, Robert F., Kevin F. McCarthy and Georges Vernez. The Mixed Economic Progress of Immigrants 1996 RAND: Santa Monica. 
Small, K. and H. Rosen (1981). "Applied Welfare Economics with Discrete Choice Models," Econometrica, 49 pp. 105-130.

Terkla, D and P. Doeringer. "Explaining Variations in Employment Growth: Structural and Cyclical Change among States and Local Areas." Journal of Urban Economics, 29, p329-348. 1991.

Topel, Robert H. "Local Labor Markets." Journal of Political Economy 94, no. 3, pt. 2 (1986): S111S144.

Treyz, George. "Causes of Changes in Wage Variation among States." Journal of Urban Economics. 29 5-62 1991.

U.S. Bureau of the Census. Statistical Abstract of the United States 1995. Washington D.C. 1995.

Welch, Finnis. "Effects of Cohort Size on Earnings: The Baby Boom Babies' Financial Bust". Journal of Political Economy. 87 \#5 October 1979; S65-S98. 


\section{Data Appendix}

The Public Use Micro Samples (PUMS) from the U.S. Census of Population and Housing from 1940, 1960-1990 are the primary data sources used in our analysis. The PUMS is the only spatially representative sample which offers information on individual characteristics, earnings, rents, state of residence, and state of residence five years before. In this Appendix, we discuss how we construct the migration, earnings, rental and finally the amenity data.

The PUMS has answers to the question "which state did you lived in five years earlier?" for the 1940,1980 and 1990 samples. We construct the share of migrants (disaggregated by age and education) who left each state five years earlier and the share who entered the state.

Measures of annual earnings are available in the PUMS from 1960 to 1990 . Our earnings regressions include males aged 25-55, who worked between 1800 and 2600 hours and were in the manufacturing, services, government or FIRE industries. Our dependent variable is the log of annual earnings net of state taxes. ${ }^{24}$ The omitted category in the hedonic earnings regression is a man in a non-professional occupation employed in the manufacturing industry who is non-white and nonmarried.

Measures of annual housing costs are available in the PUMS only from 1960 to 1990 . The housing regressions only include renters and we use the log of the monthly contract rent as our dependent variable. ${ }^{25}$ We include but suppress controls for the apartment's year built.

All census summary statistics are available on request.

Because it is difficult to collect a consistent set of local public goods by from 1960 to 1990, we only focus on climate. The climate data sources are the Statistical Abstract of the U.S. and the NOAA CD-ROM. We only use the four climate proxies, sunshine, humidity, July and February average temperature because other measures like heating and cooling days are very highly correlated with these. The climate summary statistics are:

$\begin{array}{lll}\text { Variable } & \text { mean } & \text { standard deviation } \\ \text { February temperature } & 33.7 & 10.4 \\ \text { July temperature } & 74.2 & 5.2 \\ \text { Sunshine }^{26} & 57.1 & 8.1 \\ \text { Humidity }^{27} & 79.5 & 10.3\end{array}$

${ }^{24}$ While many states have non-linear income schedules, we found that the variation can be summarized using the lowest state tax bracket as a proxy.

${ }^{25}$ By using renters we avoid the problems faced by Gyourko and Tracy $(1989,1991)$ and Blomquist, Berger and Hoehn (1988) who include both renters and owners. They use monthly rent as the dependent variable and therefore must convert home values into implicit rents.

${ }^{26}$ Average percentage of sunshine possible.

${ }^{27}$ July Afternoon average relative humidity (percent). 

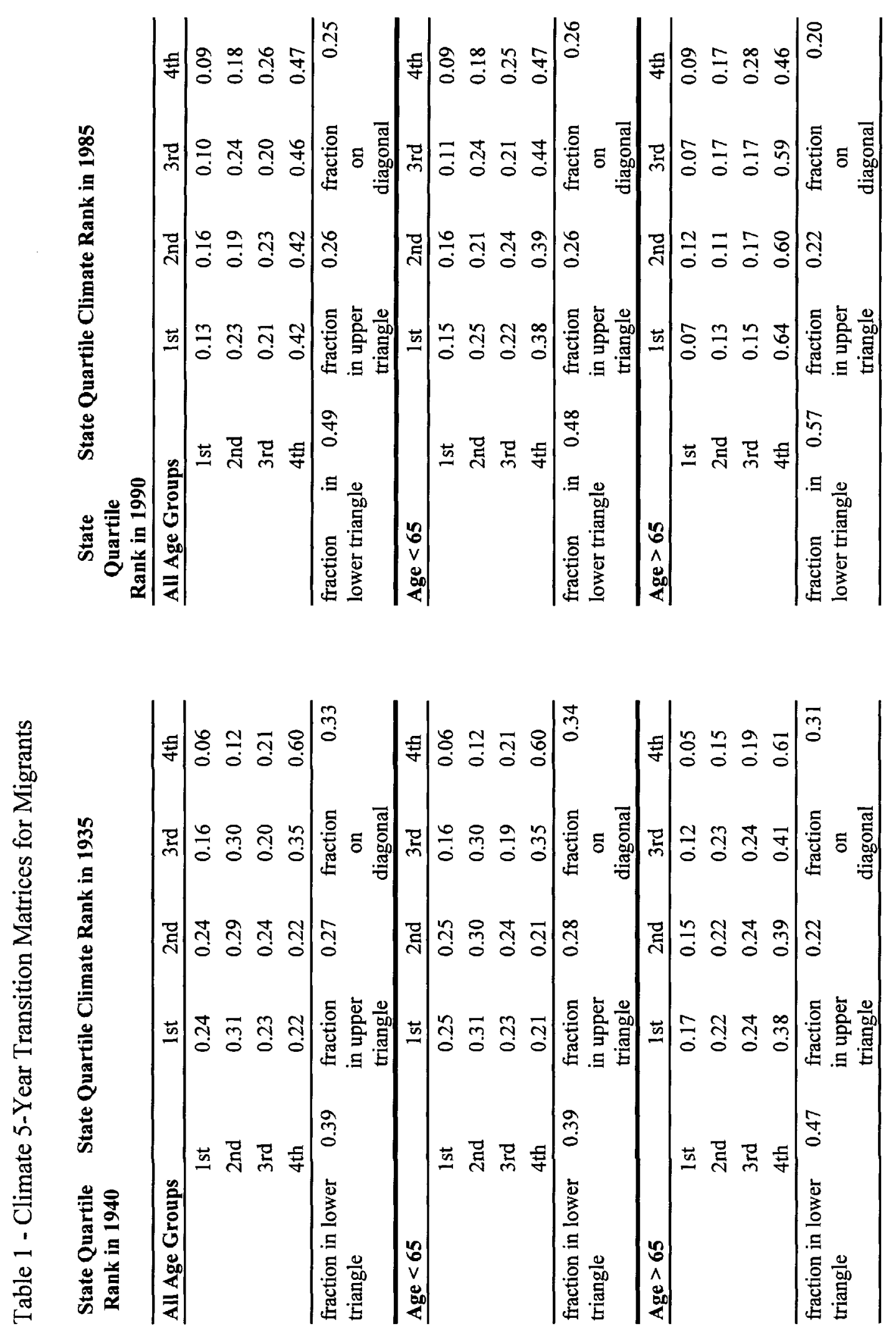
Table 2 - Net Migration Regressions

\begin{tabular}{lcccccc} 
Full Population & \multicolumn{2}{c}{$1935-40$} & \multicolumn{2}{c}{$1975-80$} & \multicolumn{2}{c}{$1985-90$} \\
\hline February temperature & $4.0 \mathrm{E}-03$ & 6.7 & $1.8 \mathrm{E}-03$ & 4.7 & $3.4 \mathrm{E}-03$ & 3.4 \\
July temperature & $-6.2 \mathrm{E}-03$ & -4.6 & $-2.1 \mathrm{E}-03$ & -2.4 & $-2.9 \mathrm{E}-03$ & -1.3 \\
Humidity & $-6.4 \mathrm{E}-04$ & -1.1 & $-9.4 \mathrm{E}-04$ & -2.5 & $-8.0 \mathrm{E}-04$ & -0.8 \\
Sunshine & $1.5 \mathrm{E}-05$ & 0.0 & $3.5 \mathrm{E}-04$ & 0.6 & $-3.1 \mathrm{E}-04$ & -0.2 \\
Constant & $3.8 \mathrm{E}-01$ & 4.7 & $1.6 \mathrm{E}-01$ & 3.0 & $1.8 \mathrm{E}-01$ & 1.3 \\
R-squared & 0.54 & & 0.45 & & 0.25 & \\
& & & & & & \\
Age $>65$ & & & & & & \\
\hline February temperature & $2.0 \mathrm{E}-03$ & 4.4 & $1.5 \mathrm{E}-03$ & 3.3 & $2.4 \mathrm{E}-03$ & 3.6 \\
July temperature & $-1.5 \mathrm{E}-03$ & -1.5 & $1.1 \mathrm{E}-04$ & 0.1 & $-3.5 \mathrm{E}-04$ & -0.2 \\
Humidity & $-4.9 \mathrm{E}-04$ & -1.2 & $-1.1 \mathrm{E}-03$ & -2.6 & $-1.3 \mathrm{E}-03$ & -2.1 \\
Sunshine & $-5.0 \mathrm{E}-05$ & -0.1 & $-7.5 \mathrm{E}-05$ & -0.1 & $-9.9 \mathrm{E}-05$ & -0.1 \\
Constant & $9.2 \mathrm{E}-02$ & 1.5 & $3.8 \mathrm{E}-02$ & 0.6 & $5.9 \mathrm{E}-02$ & 0.7 \\
R-squared & \multicolumn{2}{c}{0.37} & & 0.42 & & 0.4
\end{tabular}


Table 3 - Hedonic Log Annual Earnings Regressions (1990\$)

\begin{tabular}{|c|c|c|c|c|c|c|c|c|}
\hline & \multirow{2}{*}{$\begin{array}{r}1960 \\
\text { Coef. }\end{array}$} & \multicolumn{3}{|c|}{1970} & \multirow{2}{*}{$\begin{array}{r}1980 \\
\text { Coef. }\end{array}$} & \multicolumn{3}{|c|}{1990} \\
\hline & & t-stat. & Coef. & t-stat. & & t-stat. & Coef. & t-stat. \\
\hline Professional & 0.079 & 12.5 & 0.078 & 9.9 & 0.146 & 33.4 & 0.173 & 29.9 \\
\hline Services & -0.237 & -17.2 & -0.169 & -19.3 & -0.260 & -18.4 & -0.226 & -15.7 \\
\hline Government & -0.108 & -9.2 & -0.042 & -3.2 & -0.104 & -6.0 & -0.089 & -4.1 \\
\hline Financial or Real Estate Services & -0.048 & -4.4 & 0.014 & 1.0 & -0.059 & -5.1 & 0.023 & 1.0 \\
\hline College degree & 0.049 & 23.6 & 0.106 & 8.8 & 0.014 & 2.4 & 0.069 & 7.7 \\
\hline Years of education & 0.058 & 5.3 & 0.053 & 31.8 & 0.055 & 29.9 & 0.063 & 36.4 \\
\hline Age & 0.057 & 30.8 & 0.062 & 29.9 & 0.073 & 26.8 & 0.059 & 30.0 \\
\hline Age squared & -0.001 & -24.0 & -0.001 & -25.6 & -0.001 & -23.1 & -0.001 & -23.4 \\
\hline White & 0.295 & 14.9 & 0.260 & 12.7 & 0.194 & 13.9 & 0.145 & 9.3 \\
\hline Married & 0.126 & 20.1 & 0.112 & 20.9 & 0.091 & 13.9 & 0.090 & 21.5 \\
\hline February temperature & -0.002 & -1.7 & -0.001 & -0.8 & -0.001 & -0.9 & 0.000 & 0.2 \\
\hline July temperature & -0.008 & -1.8 & -0.009 & -2.1 & -0.006 & -1.9 & -0.011 & -3.0 \\
\hline Sunshine & 0.003 & 1.4 & 0.001 & 0.4 & 0.001 & 0.5 & 0.003 & 1.4 \\
\hline Humidity & 0.001 & 0.7 & 0.001 & 0.4 & 0.000 & 0.2 & 0.001 & 0.8 \\
\hline Constant & 8.262 & 34.5 & 8.525 & 37.4 & 8.024 & 36.3 & 8.299 & 26.5 \\
\hline Number of observations & 91,712 & & 107,186 & & 109,973 & & 111,801 & \\
\hline R-squared & 0.280 & & 0.259 & & 0.194 & & 0.256 & \\
\hline F-test of climate variables & 3.10 & & 4.74 & & 2.22 & & 3.30 & \\
\hline P-value & 0.01 & & 0.00 & & 0.06 & & 0.01 & \\
\hline \multicolumn{9}{|l|}{ Omitting California } \\
\hline & 1960 & & 1970 & & 1980 & & 1990 & \\
\hline & Coef. & t-stat. & Coef. & t-stat. & Coef. & t-stat. & Coef. & t-stat. \\
\hline Professional & 0.077 & 11.4 & 0.076 & 9.0 & 0.147 & 32.0 & 0.172 & 26.4 \\
\hline Services & -0.243 & -16.8 & -0.166 & -17.9 & -0.266 & -20.0 & -0.227 & -14.7 \\
\hline Government & -0.100 & -7.0 & -0.035 & -2.3 & -0.105 & -5.5 & -0.087 & -3.7 \\
\hline Financial or Real Estate Services & -0.039 & -3.1 & 0.026 & 2.3 & -0.061 & -5.0 & 0.023 & 0.9 \\
\hline College degree & 0.049 & 26.3 & 0.115 & 9.2 & 0.018 & 2.7 & 0.078 & 10.0 \\
\hline Years of education & 0.068 & 6.1 & 0.052 & 30.7 & 0.055 & 27.8 & 0.061 & 31.7 \\
\hline Age & 0.057 & 28.9 & 0.061 & 28.9 & 0.072 & 25.0 & 0.058 & 36.1 \\
\hline Age squared & -0.001 & -23.1 & -0.001 & -24.7 & -0.001 & -21.4 & -0.001 & -27.7 \\
\hline White & 0.289 & 14.6 & 0.257 & 12.3 & 0.189 & 12.8 & 0.136 & 8.6 \\
\hline Married & 0.132 & 20.5 & 0.117 & 21.1 & 0.097 & 13.8 & 0.090 & 18.0 \\
\hline February temperature & -0.005 & -3.4 & -0.003 & -2.1 & -0.003 & -2.7 & -0.001 & -0.6 \\
\hline July temperature & 0.016 & 3.9 & 0.013 & 3.2 & 0.010 & 2.5 & 0.004 & 0.9 \\
\hline Sunshine & -0.013 & -4.3 & -0.014 & -4.8 & -0.010 & -3.5 & -0.007 & -2.1 \\
\hline Humidity & -0.009 & -3.5 & -0.008 & -3.3 & -0.006 & -2.8 & -0.005 & -2.0 \\
\hline Constant & 8.291 & 39.5 & 8.551 & 39.3 & 8.035 & 38.2 & 8.324 & 26.4 \\
\hline Number of observations & 82,678 & & 96,391 & & 98,975 & & 101,038 & \\
\hline R-squared & 0.294 & & 0.270 & & 0.198 & & 0.254 & \\
\hline F-test of climate variables & 7.53 & & 10.25 & & 6.26 & & 3.41 & \\
\hline P-value & 0.00 & & 0.00 & & 0.00 & & 0.01 & \\
\hline
\end{tabular}


Table 4 - Hedonic Log Annual Rental Regressions (1990 \$)

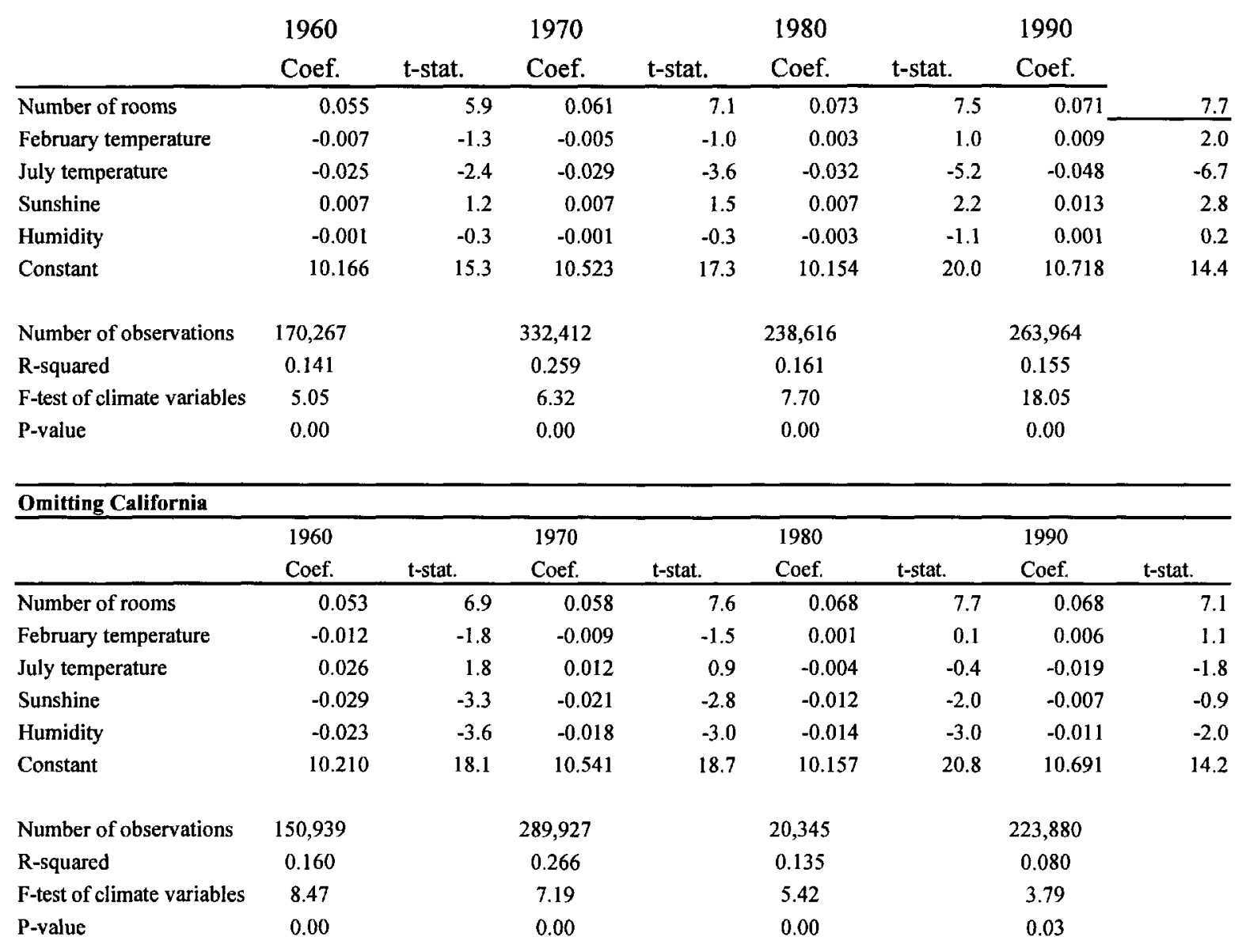

Note: Dummies for an apartment's year built are suppressed. 


\section{Table 5 - Index Numbers}

Ten year change in rental capitalization $\quad 1960-70 \quad 1970-80 \quad 1980-90$ for the nonelderly

\begin{tabular}{|c|c|c|c|}
\hline change in expenditure & $-20 \%$ & $127 \%$ & $692 \%$ \\
\hline change due to quantity changes & $23 \%$ & $28 \%$ & $16 \%$ \\
\hline change due to price changes & $-2 \%$ & $121 \%$ & $589 \%$ \\
\hline $\begin{array}{l}\text { ear change in earnings } \\
\text { alization for the nonelderly }\end{array}$ & $1960-70$ & $1970-80$ & $1980-90$ \\
\hline change in expenditure & $32 \%$ & $4 \%$ & $-27 \%$ \\
\hline change due to quantity changes & $28 \%$ & $29 \%$ & $21 \%$ \\
\hline ange due to price changes & $5 \%$ & $-20 \%$ & $-40 \%$ \\
\hline
\end{tabular}

Ten year change in combined earnings \& $1960-70 \quad 1970-80 \quad 1980-90$ rental capitalization for the nonelderly

$\begin{array}{lrrr}\text { change in expenditure } & 34 \% & 23 \% & -4 \% \\ \text { change due to quantitity changes } & 27 \% & 29 \% & 19 \% \\ \text { change due to price changes } & 5 \% & -5 \% & -20 \%\end{array}$

Ten year change in rental capitalization for $\quad 1960-70 \quad 1970-80 \quad 1980-90$ the elderly

$\begin{array}{lrrr}\text { change in expenditure } & -44 \% & 117 \% & 1,222 \% \\ \text { change due to quantitity changes } & 38 \% & 30 \% & 34 \% \\ \text { change due to price changes } & -3 \% & 114 \% & 801 \%\end{array}$

Note:

(1) Rental expenditure for the nonelderly is calculated using the number of nonelderly householders in each state by decade multiplied by rental capitalization by decade calculated using estimates from table 4 .

(2) Rental expenditure for the elderly is calculated using the number of elderly householders in each state by decade multiplied by rental capitalization by decade calculated using estimates from table 4 .

(3) Earnings expenditure for the nonelderly is calculated using the number of workers in each state by decade multiplied by earnings capitalization by decade calculated using estimates from table 3.

(4) The change in climate consumed is calculated holding prices constant at their 1990 level and calculating expenditure by decade using the relevant state population by decade.

(5) The change in prices is calculated holding populations constant at their 1990 level and calculating expenditure by decade using the relevant earnings and rental capitalization by decade. 


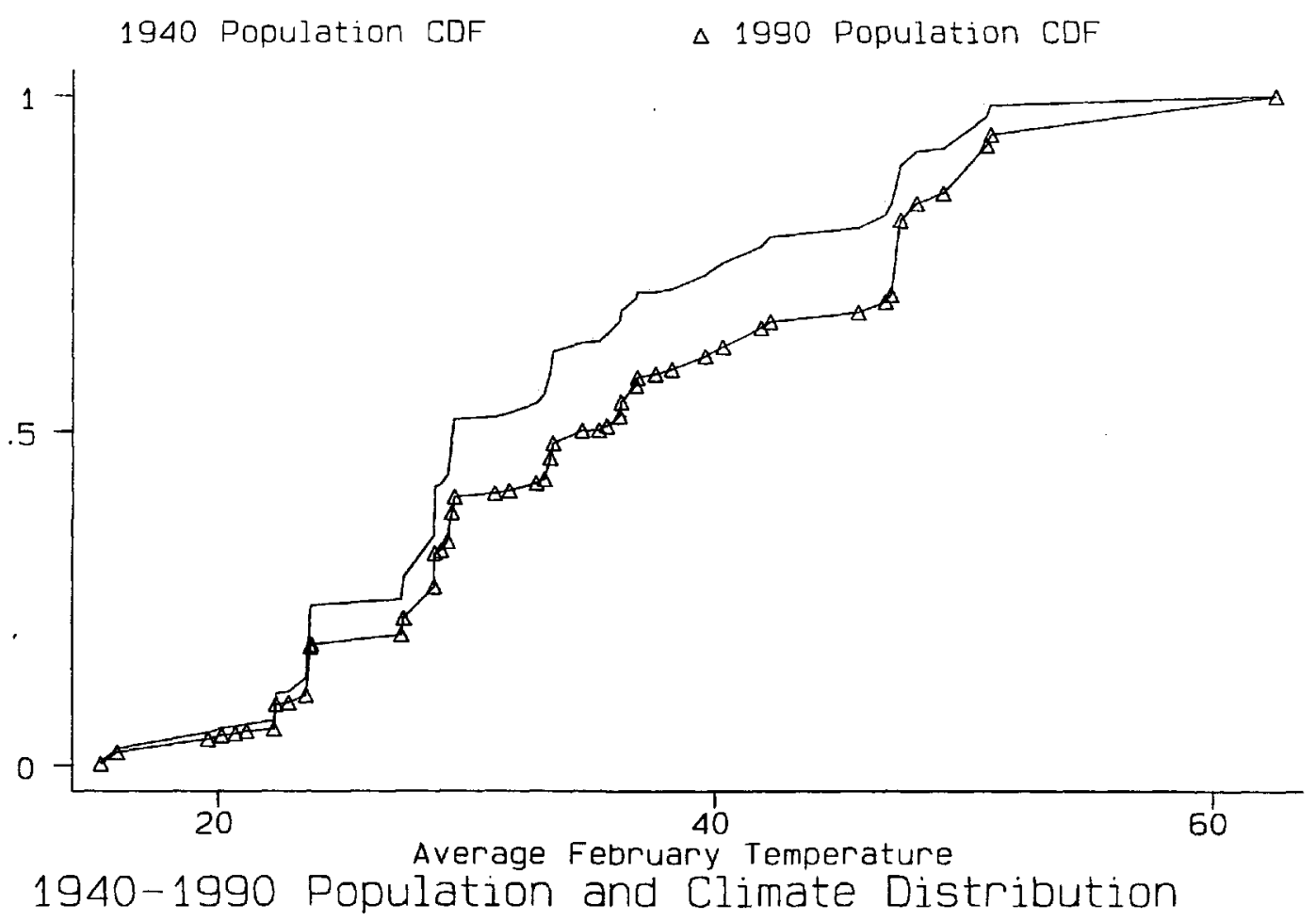




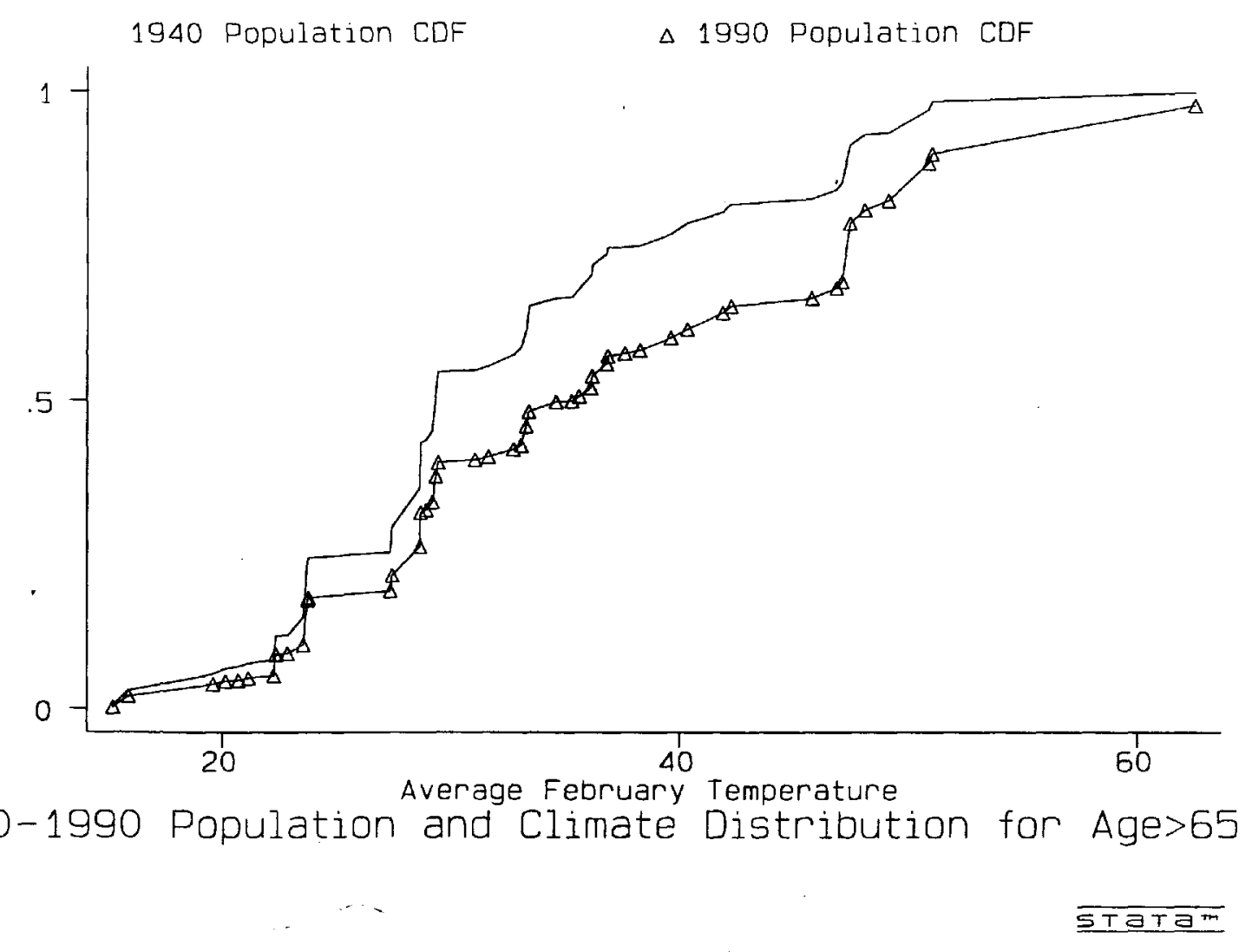


- Coldest 25th Quantile

- Warmest 50th-75th Quantile

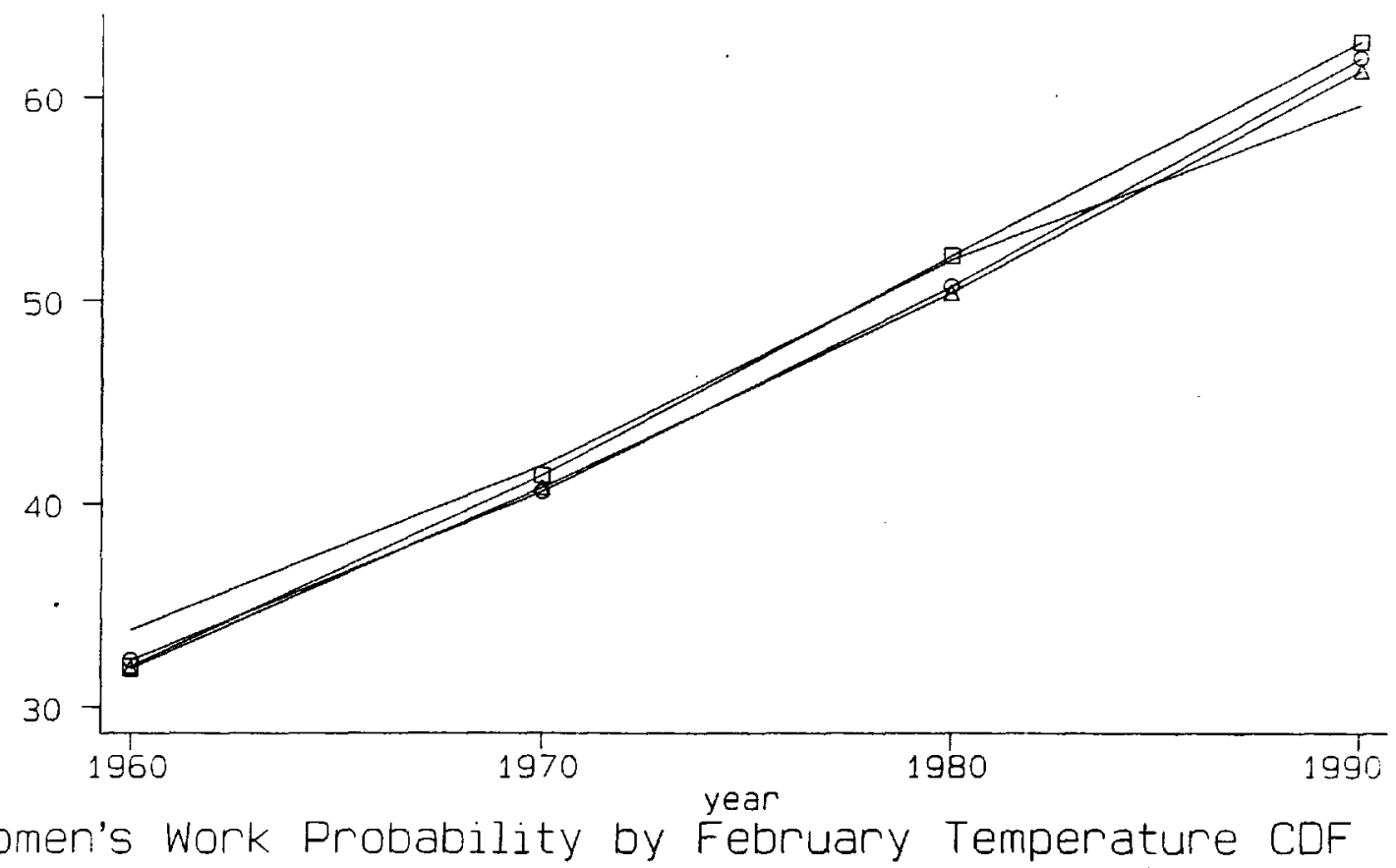

$\Delta$ Coldest 25th-50th Quantile Warmest 75 th Quantile 


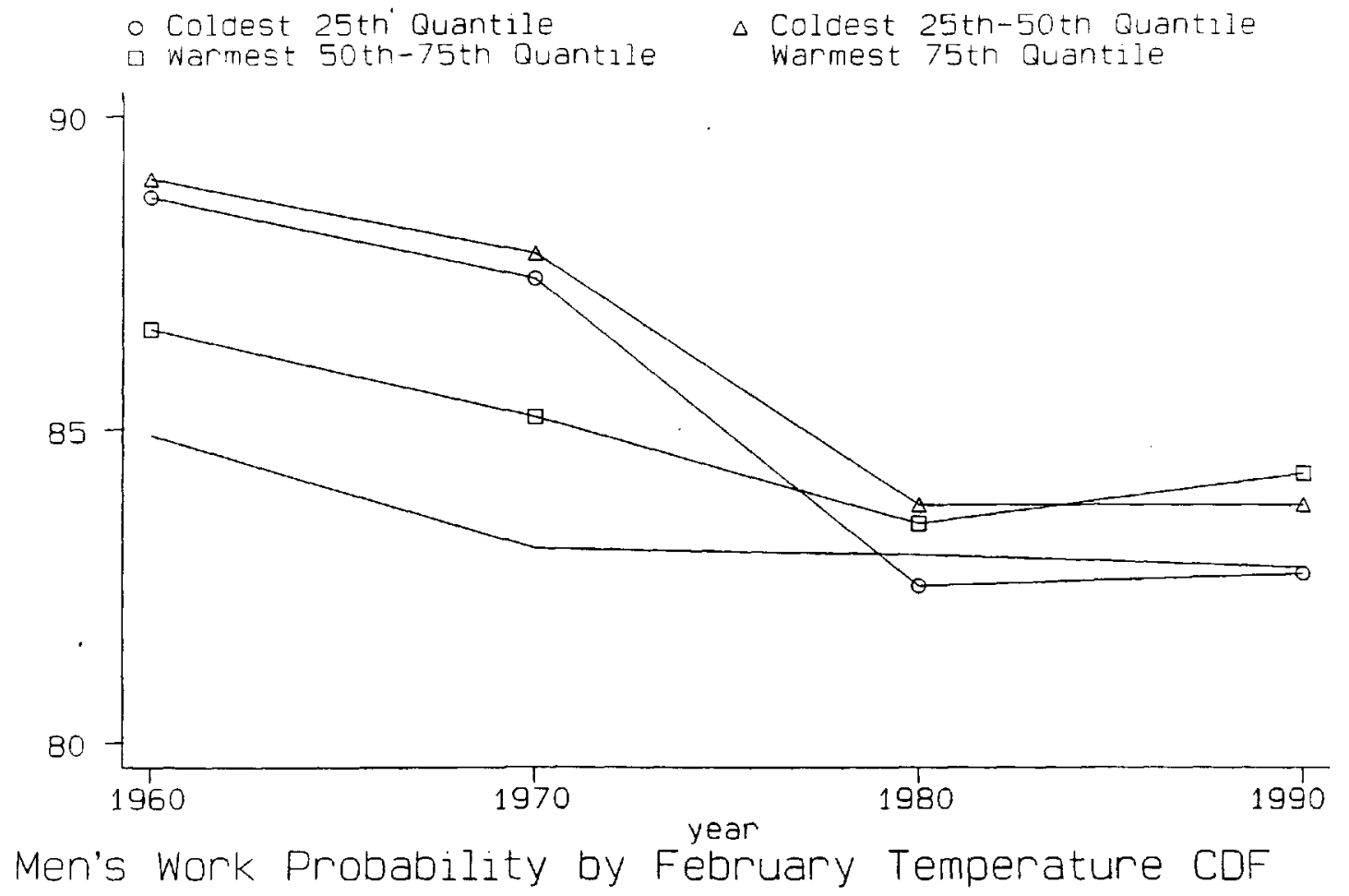


- Coldest 25th Quantile

$\square$ Warmest 50 th-75th Quantile

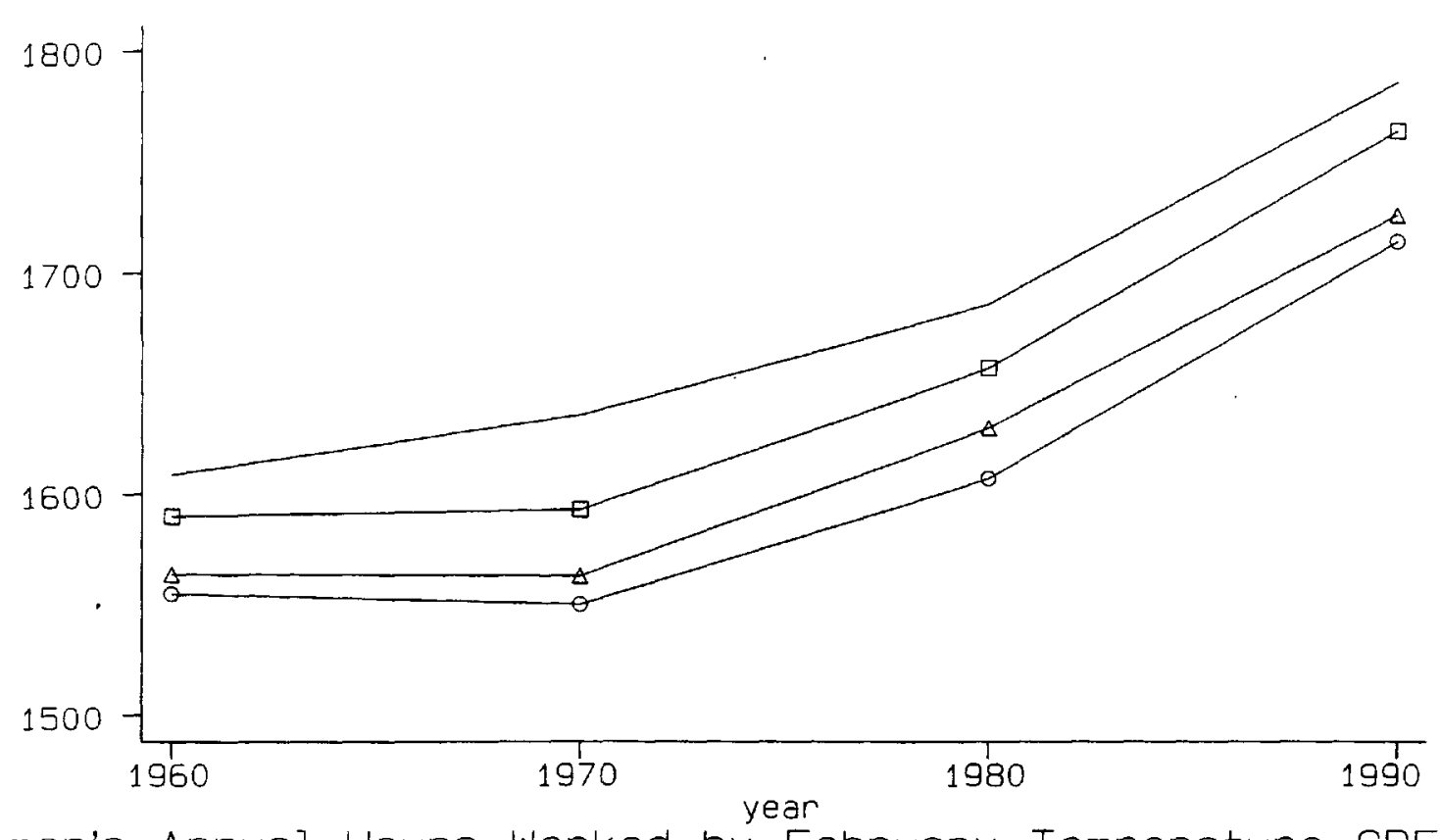

$\triangle$ Coldest 25th-50th Quantile warmest 75th Quantile 


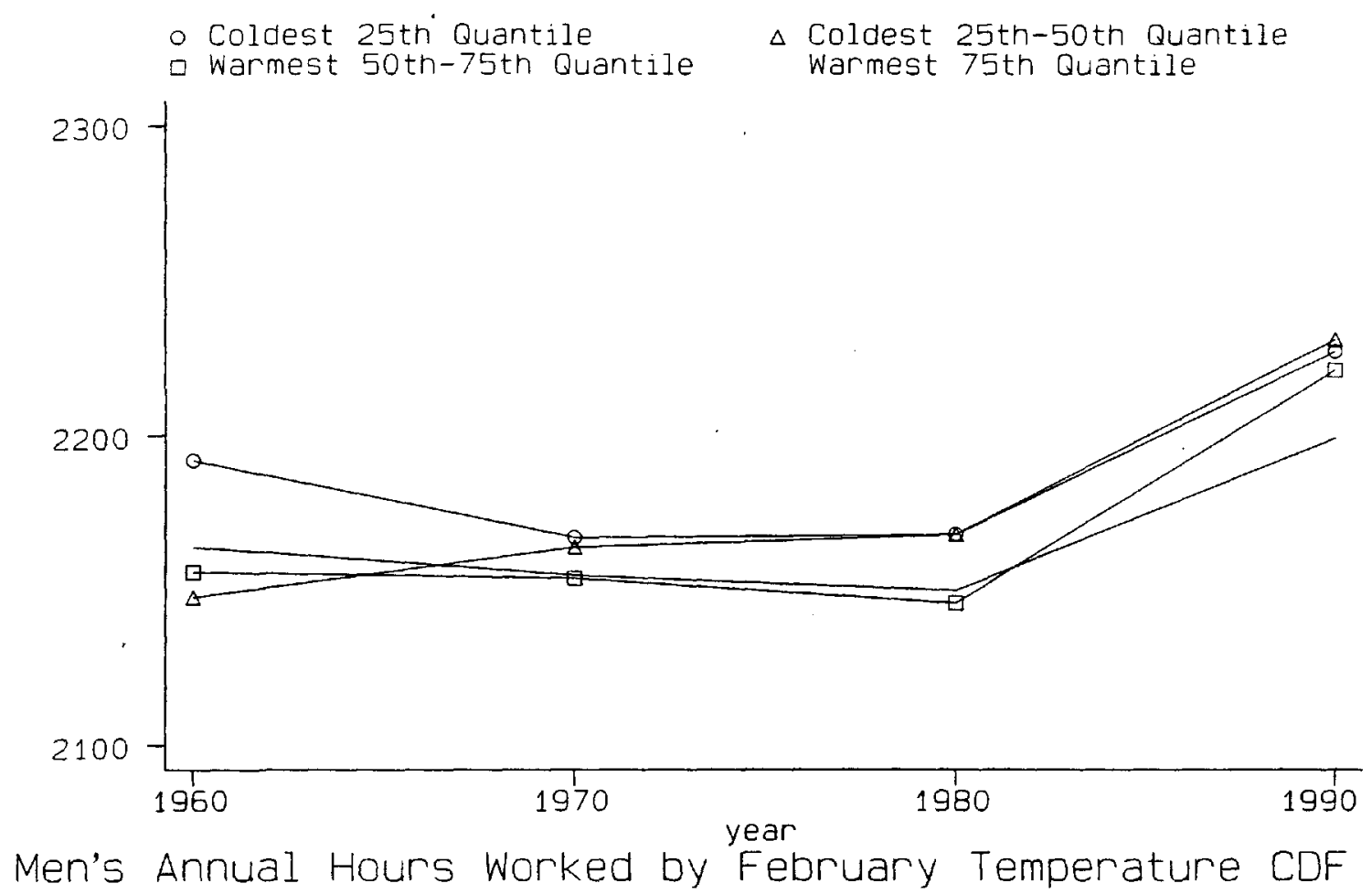




\title{
1996-1997 Discussion Paper Series
}

\author{
Department of Economics \\ Columbia University \\ 1022 International Affairs Bldg. \\ 420 West 118th Street \\ New York, N.Y., 10027
}

The following papers are published in the 1996-97 Columbia University Discussion Paper series which runs from early November to October 31 of the following year (Academic Year).

Website: $\quad$ http://www.columbia.edu/dlc/wp/econ/index.html.

You may download any papers found on this site.

\section{For Ordering Hardcopies:}

Domestic orders for discussion papers are available for purchase at the cost of $\$ 8.00$ (U.S.) Per paper and $\$ 140.00$ (US) for the series.

Foreign orders cost $\$ 10.00$ (US) per paper and $\$ 185.00$ for the series.

To order discussion papers, please write to the Discussion Paper Coordinator at the above address along with a check for the appropriate amount, made payable to Department of Economics, Columbia University. Please be sure to include the series number of the requested paper when you place an order. 
1996-97 Discussion Papers

Economics Department, Columbia University

\begin{tabular}{|c|c|c|}
\hline (x) & $8 x_{2}$ & 2. \\
\hline $9697-01$ & Fertility Behavior Under Income Uncertainty & Ranjan, P. \\
\hline $9697-02$ & Trade Restrictions, imperfect Competition and National Welfare with Foreign Capital Inflows & Ranjan, $\mathbf{P}$. \\
\hline $9697-03$ & Restructuring an Industry during Transition: a Two-Priced Model & Ericson, $\mathrm{R}$. \\
\hline $9697-04$ & A Conformity Test for Cointegration & Dhrymes, P. \\
\hline $9697-05$ & $\begin{array}{l}\text { Low-Wage Employment Subsidies in a Labor-Turnover Model of the 'Natural Rate' } \\
\text { (November 1996) }\end{array}$ & $\begin{array}{l}\text { Hoon, H.T. } \\
\text { Phelps, E. }\end{array}$ \\
\hline $9697-06$ & The Knowledge Revolution & Chichilnisky, G. \\
\hline $9697-07$ & The Role of Absolute Continuity in "Merging Opinions" and "Rational Learning" & $\begin{array}{l}\text { Miller. R. } \\
\text { Sanchirico, C.W. }\end{array}$ \\
\hline $9697-08$ & The Soviet Bloc and the Soviet Union: Why did they fall apart? & Desai, $\mathrm{P}$. \\
\hline $9697-09$ & Regionalism and Multilateral Tariff Cooperation & $\begin{array}{l}\text { Bagwell, K. } \\
\text { Staiger, R. }\end{array}$ \\
\hline $9697-10$ & Supplier Relations and the Market Context: A theory of handshakes & McLaren, J. \\
\hline $9697-11$ & Vertical Foreclosure with the Choice of Input Specifications & $\begin{array}{l}\text { Choi, J.P. } \\
\text { Yi, S. }\end{array}$ \\
\hline $9697-12$ & Equilibrium Vertical Foreclosure with Investment & $\begin{array}{l}\text { Choi, J.P. } \\
\text { Yi, S. }\end{array}$ \\
\hline $9697-13$ & Going Global: Transition from Plan to Market in the World Economy & Desai, $\mathrm{P}$. \\
\hline $9697-14$ & $\begin{array}{l}\text { Reciprocity, Non-discrimination and Preferential Agreements in the Multilateral Trading } \\
\text { System }\end{array}$ & $\begin{array}{l}\text { Bagwell, K. } \\
\text { Staiger, R. }\end{array}$ \\
\hline $9697-15$ & Russia's Transition Toward the World Economy: Is the Market Mechanism Working? & Desai, $\mathrm{P}$. \\
\hline 9697-16 & A Dynamic Analysis of Licensing: The "Boomerang" Effect and Grant-Back Clauses & Choi, J.P. \\
\hline
\end{tabular}


1996-97 Discussion Papers

Economics Department, Columbia University

\begin{tabular}{|c|c|c|}
\hline 2. & (1) & (.). \\
\hline $9697-17$ & An Economic Theory of GATT & $\begin{array}{l}\text { Bagwell, K. } \\
\text { Staiger R.W. }\end{array}$ \\
\hline $9697-18$ & Climate Consumption and Climate Pricing from 1940 to 1990 & $\begin{array}{l}\text { Cragg, M.I. } \\
\text { Kahn, M.E. }\end{array}$ \\
\hline
\end{tabular}

